\title{
EFEKTIVITAS MODEL PEMBELAJARAN QUANTUM TEACHING TERHADAP HASIL BELAJAR FISIKA SISWA SMA NEGERI JAYALOKA
}

\author{
Umi Khusnul Khotimah ${ }^{1}$, Tri Ariani ${ }^{2}$, Ovilia Putri Utami Gumay ${ }^{3}$ \\ Jurusan Pendidikan Matematika, STKIP-PGRI Lubuklinggau ${ }^{1}$ \\ Progam Studi Pendidikan Fisika, STKIP-PGRI Lubuklinggau ${ }^{2,3}$ \\ umikhusnulkhotimah19@gmail.com ${ }^{1}$
}

Submit, 26-05-2018 Accepted, 28-06-2018 Publish, 28-06-2018

\begin{abstract}
: the purpose of this study is to determine whether the model of effective teaching quantum teaching used in physics learning in SMA Negeri Jayaloka academic year 2017/2018. The methoud used is quasi eksperiment or pseudo-expansion. The type of research is quasi-experimental research, with the design used is one group pretest and posttest design. The population in this study is all students of class $X$ SMA Negeri Jayaloka academic year 2017/2018. Andasthesample isthe class X.I which amounted to32 student consisting of 17 male students and15 famale students taken at random. Data retrieval is done by test and non test technique. The collected data were analyzed using t-test at significant level $\alpha=0,05$ obtained by $\mathrm{t}_{\text {value }} 4,69>\mathrm{t}_{\text {table }} 1,69$. So it can be concluded that "student learning outcomes by using the modelof learning Quantum Teaching significant completion". Student learning activites in the learning process in the active category. While student response after following learning in good category.
\end{abstract}

Keywords: Quantum Teaching Learning Model, Learning Outcomes,

Abstrak: tujuan dari penelitian ini yaitu bertujuan untuk mengetahui apakah model pembelajaran Quantum Teaching efektif digunakan pada pembelajaran fisika di SMA Negeri Jayaloka Tahun Pelajaran 2017/2018. Metode yang digunakan adalah metode Quasi Eksperimen atau eksperimen semu, dengan desain one pre-test dan post-test. Populasi dalam penelitian ini adalah seluruh kelas X SMA Negeri Jayaloka Tahun Pelajaran 2017/2018 dan sebagai sampelnya adalah kelas X.1 yang berjumlah 32 orang siswa yang terdiri dari 17 siswa laki-laki dan 15 siswa perempuan diambil secara acak. Pengumpulan data dilakukan dengan teknik tes dan non tes. Data yang terkumpul dianalisis dengan menggunakan uji-t pada taraf signifikan $\alpha=0,05$, diperoleh nilai $t_{\text {hitung }}(4,69)>t_{\text {tabel }}(1,69)$. Jadi dapat disimpulkan bahwa "hasil belajar siswa dengan mengunakan model pembelajarn Quantum Teaching signifikan tuntas". Aktivitas belajar siswa dalam proses pembelajaran dalam kategori aktif. Sedangkan respon siswa setelah mengikuti pembelajaran dalam kategori baik.

Katakunci: Model Pembelajaran Quantum Teaching, Hasil Belajar,

\section{PENDAHULUAN}

Pendidikan merupakan salah satu bagian terpenting dalam kehidupan manusia, karena dengan pendidikan akan menentukan peradaban manusia pada masa yang akan datang. Pendidikan mempunyai peranan yang sangat strategis dalam meningkatkan kualitas sumber daya manusia dan upaya untuk mencerdaskan kehidupan bangsa. Pendidikan juga merupakan suatu proses pengembangan daya nalar, keterampilan, dan moralitas kehidupan terhadap potensi yang dimiliki oleh setiap manusia. Pendidikan dikatakan bermutu apabila proses pendidikan berlangsung secara efektif. Pendidikan juga merupakan proses pengubahan sikap dan tingkah laku seseorang atau kelompok dalam usaha mendewasakan manusia. Dalam hal ini guru berperan untuk membimbing dan mengarahkan potensi yang dimiliki siswa agar menjadi lebih baik dalam menyalurkan potensi yang dimiliki.

Berdasarkan hasil wawancara yang dilakukan peneliti dengan salah satu guru mata pelajaran Fisika di SMA Negeri Jayaloka pada tanggal 14 Februari 2017 diperoleh informasi bahwa hasil belajar 
pembelajaran yang digunakan masih menggunakan metode ceramah dan penugasan latihan soal-soal.

Dalam pembelajaran, guru lebih aktif dibandingkan siswa, siswa di dalam kelas hanya mendengar, mencatat, dan menghafal, sangat sedikit siswa yang berani menjawab pertanyaan dari guru maupun yang mengajukan pertanyaan kepada guru, banyak siswa yang tidak menampilkan hasil pekerjaannya.

Berdasarkan hasil belajar diketahui juga bahwa rata-rata nilai ulangan harian fisika siswa pada beberapa kompetensi dasar belum mencapai tingkat Kriteria Ketuntasan Minimal (KKM) belajar yang ditetapkan yaitu sebesar 75. Adapun Ratarata hasil ulangan harian siswa yang belum mencapai KKM Sebanyak 70 siswa atau $35,89 \%$, sedangkan yang mencapai KKM yaitu 125 siswa atau $64,10 \%$ dengan jumlah siswa kelas $\mathrm{X}$ secara keseluruhan yaitu 195 siswa.

Salah satu alternatif untuk mengatasi permasalahan tersebut yaitu dengan menggunakan model pembelajaran partisipatif, aktif, dan menarik sehingga dapat menarik minat siswa dalam belajar. Penggunaan model pembelajaran aktif dan menarik yang tepat merupakan upaya yang perlu dilakukan oleh seorang guru guna tercapainya tujuan pembelajaran.

Adapun model pembelajaran yang dapat digunakan untuk mengatasi masalah tersebut salah satunya yaitu model Quantum Teaching. Model Quantum Teaching merupakan pengubahan belajar yang meriah, dengan segala nuansanya dan Quantum Teaching juga menyertakan segala kaitan, interaksi, dan perbedaan yang memaksimalkan momen belajar (DePorter et. al, 2010). Pada proses pembelajaran kuantum mampu menciptakan interaksi dan keaktifan siswa, sehingga kemampuan, bakat, dan potensi siswa dapat berkembang, yang pada akhirnya mampu meningkatkan prestasi belajar dengan menyingkirkan hambatan belajar melalui penggunaan cara dan alat yang tepat, sehingga siswa dapat belajar secara mudah dan juga guru dan siswa yang terlibat dalam proses pembelajaran sama-sama merasa senang dan saling bekerja sama untuk mencapai hasil yang maksimal

Berdasarkan permasalahan pada uraian di atas, agar pengajaran dapat mencapai hasil yang sesuai dengan tujuan yang direncanakan, maka guru perlu mempertimbangkan strategi belajar mengajar yang tepat.

\section{LANDASAN TEORI}

Pengajaran dianggap setara dan identik dengan pembelajaran dengan siswa yang aktif. Pengajaran didefinisikan sebagai transformasi dari pengetahuan sains. Selain itu pengajaran dipandang sebagai suatu sistem yang terdiri dari komponen-komponen yang bergantung satu sama lain, dan terorganisir antara kompetensi yang harus diraih siswa, materi pelajaran, pokok bahasan, metode dan pendekatan pengajaran.

Trianto (2009) efektivitas pembelajaran adalah hasil yang diperoleh siswa setelah melaksanakan proses belajar mengajar. Untuk mengetahui keefektifan mengajar dapat dilakukan dengan memberikan tes, karena hasil tes dapat dipakai untuk evaluasi berbagai aspek proses pengajaran.

Menurut Muhli (2014) terdapat beberapa indikator efektivitas pemberlajaran yaitu:

1. Ketuntasan belajar, pembelajaran dapat dikatakan tuntas apabila sekurangkurangnya 75 persen dari jumlah siswa telah memperoleh nilai sesuatu dengan KKM yang diterapkan.

2. Ketuntasan belajar ditunjukan untuk mengetahui seberapa banyak tujuan pembelajaran yang dicapai oleh siswa .

3. Model pembelajaran dikatakan efektif meningkatkan hasil belajar siswa apabila secara statistik hasil belajar siswa menunjukkan perbedaan yang 
signifikan antara pemahaman awal dengan pemahaman setelah pembelajaran (gain yang signifikan).

Dari pembahasan di atas dapat disimpulkan bahwa indikator efektivitas padapenelitian ini yaitu:

1. Hasil belajar tuntas.

2. Aktivitas siswa selama pembelajaran aktif.

3. Respon siswa dalam pembelajaran tergolong baik.

De Porter (2010) Quantum Teaching adalah pengubahan belajar yang meriah, dengan segala nuansanya. Dan Quantum Teaching juga menyertakan segala kaitan, interaksi dan perbedaan yang memaksimalkan momen belajar dan berfokus pada hubungan dinamis dalam lingkungan kelas interaksi yang mendirikan landasan dan kerangka untuk belajar.

Langkah-langkah pembelajaran

Quantum Teaching yaitu sebagai berikut:

1. Pemberian Rangsangan

Guru memberikan pertanyaan kepada siswa tentang materi prasyarat guna untuk mengkaji pengetahuan siswa.

2. Perumusan Masalah

Guru memberikan contoh pada kehidupan sehari-hari untuk merangsang pemahaman siswa dalam merumuskan suatu maslah.

3. Melakukan Percobaan Untuk Mengumpulkan Data

Guru membentuk siswa menjadi beberapa kelompok, guru memberikan Lembar Kerja Siswa (LKS) kepada tiap-tiap kelompok, kemudian setiap kelompok melakukan pembagian tugas agar semua siswa dapat mencermati dan mengumpulkan data atau informasi sebanyak mungkin.

4. Menganalisis Data

Siswa diberi kesempatan untuk mencermati dan menjawab pertanyaan LKS yang telah diberikan kemudian menganalisis datanya. Kemudian guru memberi kesempatan kepada siswa untuk mempresentasikan hasil praktikum yang di dapat atau diperoleh.
5. Memberikan Apresiasi

Guru memberikan pujian kepada kelompok siswa atas keberhasilan dalam menyelesaikan tugasnya dengan cara melakukan tepuk tangan secara bersama-sama kepada siswa.

6. Menarik Kesimpulan

Guru dan siswa secara bersama-sama menarik kesimpulan dari hasil percobaan yang telah diperoleh atau didapat.

\section{METODE PENELITIAN}

Berdasarkan permasalahan yang diteliti jenis penelitian ini adalah penelitian kuantitatif dengan metode penelitian eksperimen semu (quasy eksperiment) yang dilaksanakan tanpa adanya kelas pembanding.

Desain penelitian dalam penelitian ini adalah one group pretest dan postest design. Desain penelitian ini dapat dilihat pada tabel 1 .

Tabel 1. Desain Penelitian

\begin{tabular}{ccc}
\hline Pre-test & Treatment & Post-test \\
\hline $\mathrm{O}_{1}$ & $\mathrm{X}$ & $\mathrm{O}_{2}$ \\
\hline
\end{tabular}

Sumber : Sugiyono (2015:8110-111)

Keterangan:

$\mathrm{O}_{1}=$ Nilai tes awal

$\mathrm{O}_{2}=$ Nilai tes akhir

$\mathrm{X}=$ Treatment (model pembelajaran Quantum Teaching)

Variabel pada penelitian ini terdiri atas: (1) variabel bebas yaitu model pembelajaran Quantum Teaching, dan (2) variabel terikat yaitu hasil belajar fisika siswa, aktivitas siswa dan respon siswa.

Penelitian ini diadakan di SMA Negeri Jayaloka tahun pembelajaran 2017/2018. Populasi dalam penelitian ini adalah seluruh siswa kelas X SMA Negeri Jayaloka tahun pelajaran 2017/2018 yang terdiri dari enam kelas.

Sampel penelitian ini adalah seluruh siswa kelas X.I SMA Negeri Jayaloka yang berjumlah 32 siswa. Sampel ini ditentukan dengan teknik Simple Random 
Sampling atau pengambilan sampel secara acak. Teknik pengumpulan data pada penelitian ini yaitu:

1. Tes, berupa soal essay sebanyak delapan soal.

2. Non tes, menggunakan dua instrumen yaitu : observasi aktivitas siswa dan angket respon siswa.

Dalam penelitian ini, analisis data yang dilakukan terhadap data hasil belajar siswa sebagai berikut :

\section{Analisis Data Tes}

Mencari nilai rata-rata dan simpangan baku

Mencari nilai rata-rata dan simpangan baku pada tes awal dan tes akhir menggunakan rumus:

$$
\begin{array}{cc}
\bar{x}=\frac{\sum x_{i}}{n} & (\text { Sudjana, 2005) } \\
s=\sqrt{\frac{\sum\left(x_{i}-\bar{x}\right)^{2}}{n-1}} & (\text { Sugiyono, 2006) }
\end{array}
$$

Keterangan:

$s$ = simpangan baku

$x_{i}=$ nilai siswa keseluruhan

$\bar{x}=$ nilai rata-rata sampel

$n$ = banyaknya siswa dalam sampel

\section{Uji normalitas}

Uji normalitas bertujuan untuk mengetahui apakah data berdistribusi normal atau tidak. Perhitungan uji normalitas distribusi ini menggunakan rumus Chi-kuadrat sebagai berikut:

$$
\chi^{2}=\sum \frac{\left(f_{0}-f_{h}\right)^{2}}{f_{h}}
$$

Keterangan:

$\chi^{2}=$ chi-kuadrat yang dicari

$f_{0}=$ frekuensi dari hasil pengamatan

$f_{h}=$ frekuensi yang diharapkan

Selanjutnya $\chi_{\text {hitung }}^{2}$ dibandingkan terhadap $\chi_{\text {tabel }}^{2}$ dengan derajat kebebasan $(\mathrm{dk})=\mathrm{k}-1$, dimana $\mathrm{k}$ adalah banyaknya kelas interval. Jika $\chi_{\text {hitung }}^{2}<\chi_{\text {tabel }}^{2}$, maka data tersebut terdistribusi normal, dan jika $\chi_{\text {hitung }}^{2} \geq \chi_{\text {tabel }}^{2}$ maka data tidak terdistribusi normal.

\section{Uji Hipotesis}

Karena simpangan baku populasi tidak diketahui dan data berdistribusi normal, maka untuk menguji hipotesis menggunakan t-tes satu sampel dengan rumus dibawah ini:

$$
t=\frac{\bar{x}-\mu_{0}}{\frac{s}{\sqrt{n}}}
$$

Keterangan:

$t=$ nilai $t$ yang dihitung

$\bar{x}=$ nilai rata-rata

$\mu_{0}=$ nilai yang dihipotesis

$s$ = simpangan baku sampel

$n=$ jumlah anggota sampel

Kriteria pengujiannya adalah Jika $t_{\text {hitung }} \leq t_{\text {tabel }}$ maka $\mathrm{H}_{0}$ diterima dan $\mathrm{H}_{\mathrm{a}}$ ditolak. Sebaliknya jika $t_{\text {hitung }}>t_{\text {tabel }}$ maka $\mathrm{H}_{0}$ ditolak dan $\mathrm{H}_{\mathrm{a}}$ diterima. Dimana $\mathrm{t}_{\text {tabel }}$ didapatkan dari daftar distribusi t dengan ( $\alpha=0,05), \mathrm{dk}=\mathrm{n}-1$.

\section{HASIL DAN PEMBAHASAN}

Tabel 2 Nilai Pre-test dan Post-test

\begin{tabular}{llcc}
\hline No. & Statistik & \multicolumn{2}{c}{ Nilai } \\
\cline { 2 - 4 } & & Pre-test & Post-test \\
\hline 1. & $\begin{array}{l}\text { Ukuran } \\
\text { sampel }\end{array}$ & 32 & 32 \\
\hline 2. & rata-rata & 16,53 & 46,28 \\
\hline 3. & $\begin{array}{l}\text { Simpangan } \\
\text { baku }\end{array}$ & 15,32 & 34,53 \\
\hline 4. & $\begin{array}{l}\text { Nilai } \\
\text { maksimum }\end{array}$ & 47 & 95 \\
\hline 5. & $\begin{array}{l}\text { Nilai } \\
\text { minimum }\end{array}$ & 7 & 67 \\
\hline 6. & $\begin{array}{l}\text { Siswa yang } \\
\text { tuntas }\end{array}$ & 0 siswa \\
\hline 7. & $\begin{array}{l}\text { Siswa yang } \\
\text { tidak tuntas }\end{array}$ & $\begin{array}{l}32 \text { siswa } \\
(100 \%)\end{array}$ & $\begin{array}{l}4 \text { siswa } \\
(12,5 \%)\end{array}$ \\
\hline & \multicolumn{2}{c}{ siswa } \\
\hline
\end{tabular}


Tabel di atas menunjukan bahwa nilai rata-rata pre-test siswa adalah 16,53 dan nilai rata-rata post-test adalah 46,28. Hal ini menujukan bahwa telah terjadi peningkatan hasil belajar setelah diterapkan model pembelajaran Quantum Teaching yaitu sebesar $29,75 \%$. Nilai ratarata post-test sebesar 46,28 telah memenuhi nilai kreteria ketuntasan minimal (KKM) mata pelajaran Fisika di SMA Negeri Jayaloka.

Untuk menarik kesimpulan dari data tes akhir, maka dilakukan pengujian hipotesis secara statistik, Namun sebelum pengujian dilakukan terlebih dahulu dilakukan uji normalitas.

Uji normalitas bertujuan untuk melihat apakah data hasil tes siswa berdistribusi normal atau tidak. Berdasarkan ketentuan perhitungan statistik mengenai uji normalitas dengan taraf kepercayaan $\alpha=0,05$, jika $\chi^{2}{ }_{\text {hitung }}<$ $\chi_{\text {tabel }}^{2}$ maka data terdistribusi normal. Kemudian jika $\chi^{2}{ }_{\text {hitung }}>\chi_{\text {tabel }}^{2}$, maka data terdistribusi tidak normal. Hasil uji normalitas data hasil belajar siswa dapat dilihat pada tebel 3

Tabel 3. Hasil Uji Normalitas

\begin{tabular}{ccccc}
\hline Data & $\chi^{2}{ }_{\text {hitung }}$ & Dk & $\chi^{2}{ }_{\text {tabel }}$ & $\begin{array}{c}\text { Kesimpu } \\
\text { lan }\end{array}$ \\
\hline Normalitas & 10,5716 & 5 & 11,7 & Normal \\
\hline
\end{tabular}

Berdasarkan Tabel 3 menunjukkan nilai uji $\chi_{\text {hitung }}^{2}$ data hasil belajar siswa lebih kecil daripada $\chi_{\text {tabel }}^{2}$ sehingga dapat disimpulkan bahwa data tersebut berdistribusi normal, maka untuk menguji hipotesis menggunakan uji $\mathrm{t}$ dengan taraf kepercayaan $\alpha=0,05$, jika $t_{\text {hitung }}>t_{\text {tabel }}$, hal ini berarti $\mathrm{H}_{0}$ ditolak dan $\mathrm{H}_{\mathrm{a}}$ diterima. Hasil uji-t data pre-test dan post-test dapat dilihat pada Tabel 4.

Tabel 4. Hasil Uji Hipotesis

\begin{tabular}{|c|c|c|c|c|}
\hline Data & $\mathrm{t}_{\text {hitun }}$ & $\begin{array}{l}\text { dk (n- } \\
1)\end{array}$ & $t_{\text {tabel }}$ & Keterangan \\
\hline Uji-t & 4,69 & 31 & 1,69 & $\begin{array}{l}\text { Ha diterima, } \\
\text { ditolak }\end{array}$ \\
\hline
\end{tabular}

Berdasarkan Tabel 4 dapat dilihat bahwa hasil uji-t post-test menunjukkan nilai $t_{\text {hitung }}(4,69)>t_{\text {tabel }}(1,69)$, hal ini berarti $\mathrm{H}_{0}$ ditolak dan $\mathrm{H}_{\mathrm{a}}$ diterima artinya hasil belajar siswa setelah mengikuti pembelajaran fisika dengan menggunakan model pembelajaran Quantum Teaching lebih dari sama dengan 75 .

Berdasarkan uraian tersebut dapat dilihat gambaran data lebih jelas, diketahui nilai rata-rata untuk pre-test sebesar 16,53 dan nilai rata-rata untuk post-test yaitu 46,28. Artinya terdapat peningkatan rata-rata sebesar 29,75\% setelah diterapkan model pembelajaran Quantum Teaching pada materi kalor di SMA Negeri Jayaloka. Secara rinci peningkatan hasil belajar ini dapat dilihat pada Gambar 1.

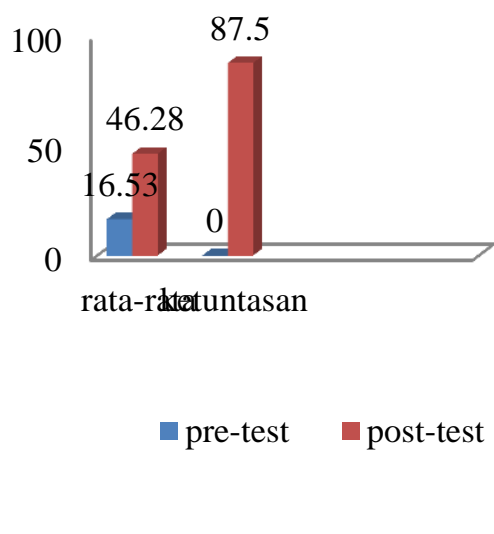

Gambar 1 Grafik Nilai Rata-rata Pre-test dan Post-test

Berdasarkan Gambar 1 dapat disimpulkan bahwa hasil belajar fisika siswa kelas X SMA Negeri Jayaloka tahun pelajaran 2017/2018 setelah penerapan model pembelajaran Quntum Teacing signifikan tuntas.

Berdasarkan hasil penelitian yang dilakukan (tabel 2) dapat kita lihat perbedaan nilai siswa secara signifikan antara nilai pre-test dan nilai post-test. Hal ini membuktikan bahwa ada peningkatan nilai siswa setelah diterapkan model pembelajaran Quantum Teaching pada materi kalor di SMA Negeri Jayaloka. 
Pada pertemuan pertama dilaksanakan pada tanggal 30 Januari 2018 diikuti 32 siswa. Kegiatan pembelajaran pertama ini dilakukan menggunakan model pembelajaran Quantum Teaching dengan materi kalor. Diawal pembelajaran guru menjelaskan kompetensi (tujuan) yang akan dicapai. Kemudian membagi siswa menjadi beberapa kelompok.

Masing-masing kelompok kemudian diberian Lembar Kerja Siswa (LKS). Sebelum siswa melakukan praktikum guru terlebih dahulu menampilkan vidio tentang percobaan guna untuk memudahkan proses jalannya praktikum. Peneliti bersama-sama siswa memerisa dan membahas lembar kerja siswa pada masing-masing aktivitas. Setelah itu guru dan siswa secara bersamaan menyimpulkan hasil percobaan yang telah dilakukan.

Diakhir pembelajaran sebelum guru menutup pembelajaran guru meninstruksikan kepada siswa untuk mempelajari materi yang akan dipelajari pada pertemuan selanjtnya yaitu mengenai perubahan wujud benda.

Pertemuan kedua dilaksanakan pada tanggal 06 Februari 2018 yang kegiatan pembelajarannya masih sama seperti pertemuan pertama tanpa mengubah susunan kelompok. Pada pertemuan ini diikuti oleh 32 siswa dengan materi ajar perubahan wujud benda. Pada pertemuan ini terlihat terdapat peningkatan aktivitas yang lebih baik dalam mengikuti pembelajaran (praktikum).

Hal ini dapat dilihat dari kekompakkan dan keaktifan siswa dalam melakukan percobaan. Hal ini dikarenakan karena mereka sudah mulai terbiasa dengan kelompok yang dibentuk.

Setelah kegiatan pembelajaran maka dilakukan post-test yang hasil perhitungan post-test didapatkan nilai ratarata hasil post-test adalah 46,28, nilai terendahnya adalah 67 , nilai tertingginya adalah 95 serta simpangan bakunya adalah
34,53. Dan hasil uji-t post-test menunjukkan bahwa $t_{\text {hitung }}(4,69)>t_{\text {tabel }}$ $(1,69)$, hal ini berarti $\mathrm{H}_{0}$ ditolak dan $\mathrm{H}_{\mathrm{a}}$ diterima artinya rata-rata hasil belajar siswa setelah mengikuti pembelajaran fisika dengan menggunakan model pembelajaran Quantum Teaching lebih dari atau sama dengan $75(\mu \geq 75)$.

Berdasarkan hasil analisis data posttest terdapat peningkatan pada hasil belajar fisika siswa. Hal ini disebabkan peneliti melakukan proses pembelajaran dengan menggunakan model Pembelajaran Quantum Teaching. Model pembelajaran ini memungkinkan semua siswa terlibat langsung dan aktif, serta melalui model Quantum Teaching ini membuat mereka merasa bahwa proses pembelajaran menjadi menarik dan menyenangkan sehingga tidak menimbulkan kebosanan dan siswa tidak merasa dipaksakan. Sehingga diharapkan model pembelajaran Quantum Teaching ini dapat menjadikan siswa lebih aktif dalam proses pembelajaran.

Pada pertemuan pertama dilihat pada lembar aktivitas siswa bahwa nilai 12 siswa kategori kurang aktif, 18 siswa kategori cukup aktif, dan 2 siswa kategori aktif, nilai rata-rata aktivitas siswa pada pertemuan pertama adalah $31,34 \%$ dengan kriteria cukup aktif. Pada pelaksanaan pembelajaran berlangsung hanya ada beberapa siswa yang aktif dalam proses pembelajaran selebihnya siswa cenderung pasif.

Hal ini dilihat dari hanya ada beberapa siswa yang berani bertanya kepada guru mengenai permasalahan yang sedang dilakukan selama praktikum. Hal ini dimungkinkan karena mereka belum terbiasa dengan kelompok yang dibuat oleh guru. Selain itu terdapat beberapa siswa yang merasa tidak cocok dengan siswa lain dalam kelompoknya, sehingga terkadang terjadi sedikit perselisihan dan ada juga beberapa siswa yang dapat dikategorikan berkemampuan tinggi 
namun sikap sosial dalam beradaptasi kurang, merasa tidak nyaman ketika harus dikelompokkan dengan siswa yang berkemampuan dibawah mereka.

Hal ini berakibat pada tidak terbangunnya kerjasama dalam kelompok tersebut. Sehingga pada proses pembelajaran pertama menyebabkan sebagian dari mereka belum bisa mengikuti proses pembelajaran dengan baik.

Pada pertemuan kedua tampak ada peningkatan aktivitas yang lebih baik hal ini terlihat dari kekompakkan dan keakifan siswa dalam melaksanakan pembelajaran. Tetapi pada pertemuan kedua ini masih ada beberapa siswa juga yang masih belum aktif. Adapun aktivitas siswa pada pertemuan kedua ini yaitu 6 siswa kategori cukup aktif, 8 siswa kategori aktif, dan 18 siswa kategori sangat aktif, nilai rata-rata aktivitas siswa pada pertemuan kedua $5,2 \%$ dengan kriteria aktif. Ini berarti dengan diterapkannya model pembelajaran Quantum Teaching siswa mulai merasa tertarik dan akitf ketika proses pembelajaran berlangsung.

Berdasarkan analisis angket respon siswa terhadap pembelajaran dengan menggunakan model pembelajaran Quantum Teaching didapatkan bahwa rata-rata respon siswa terhadap 16 indikator angket yang diikuti oleh 32 siswa hasilnya yaitu dalam kategori baik dengan persentase $68 \%$. Adapun Indikator pernyataan dengan persentase yang sangat baik terdapat pada indikator nomor pernyataan 2, 7, 9 dan 16. Sedangkan indikator pernyataan persentase yang baik terdapat pada indikator $1,4,6,8,10,11$, 13,14,15.Selanjutnya untuk nomor pertanyaan persentase yang cukup baik terdapat pada indikator 3,5 dan 12 .

\section{SIMPULAN}

Berdasarkan hasil analisis data penelitian dan pembahasan yang telah diuraikan sebelumnya maka dapat disimpulkan sebagai berikut:

1. Berdasarkan analisis data penelitian yang dilakukan dikelas X SMANegeri Jayaloka Tahun Pelajaran 2017/2018,dapat disimpulkan bahwa nilai rata-rata hasil post-test adalah 46,12 dengan nilai simpangan bakunya 34,22. Nilai $t_{\text {hitung }}=4,69$ dan nilai $t_{\text {tabel }}$ $=1,69$ Sehingga $t_{\text {hitung }}>t_{\text {tabel }}$. Dari data tersebut maka $\mathrm{H}_{\mathrm{a}}$ diterima dan $\mathrm{H}_{0}$ ditolak. Dapat disimpulkan bahwa hasil belajar fisika siswa dengan menggunaka model pembelajaran Quantum Teaching di kelas X.1 SMA Negeri Jayaloka Tahun Pelajaran 2017/2018 secara signifikan tuntas.

2. Aktivitas siswa selama penerapan model pembelajaran Quantum Teaching berdasarkan analisis dari hasil pengamatan aktivitas siswa selama proses pembelajaran oleh observasi dalam kategori aktif yaitu dengan persentase $87,54 \%$.

3. Respon siswa setelah penerapan model pembelajaran Quantum Teaching berdasarkan analisis menunjukkan adanyarespon baik terhadap pembelajaran fisika dengan menggunakan model pembelajaran Quantum Teaching dengan persentase $77 \%$. 


\section{DAFTAR PUSTAKA}

Muhli. (2014). Inovasi Pembelajaran.

Bandung: Alphabeta

Porter, D. (2010). Quantum Teaching : Mempraktikkan Quantum Learning di Ruang-ruang Kelas. Bandung: Kaifa.

Sudjana. (2005). Metoda Statistika. Bandung: Tarsinto.

Sugiyono. (2006). Metode Penelitian Administrasi. Bandung: Alpabeta

Sugiyono. (2015). Statistika Untuk Penelitian. Bandung: Alfabeta.

Trianto. (2009). Mendesain Model Pembelajaran Inovatif-Progresif : Konsep, Landasan, dan Implementasinya pada Kurikulum Tingkat Satuan Pendidikan (KTSP). Jakarta: Kencana. 